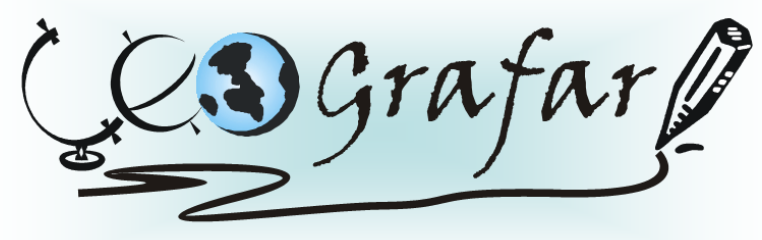

Revista Eletrônica do Programa de Pós-Graduação em Geografia - UFPR

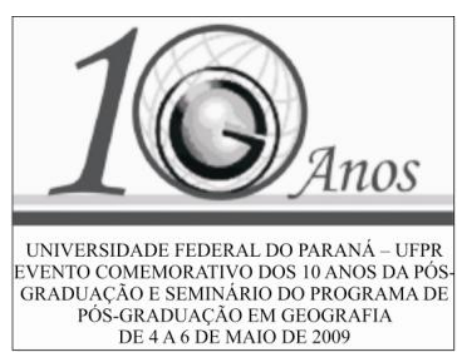

\title{
AS OPÇÕES DE LAZER DOS ESPAÇOS LIVRES PÚBLICOS EM CURITIBA/PR: A PARTICIPAÇÃO POPULAR COMO BASE PARA A ELABORAÇÃO DE UMA CARTOGRAFIA DE OPÇÕES
}

\author{
SIMONE VALASKI ${ }^{1}$ \\ JOÃO CARLOS NUCCI ${ }^{2}$
}

\section{LINHA DE PESQUISA: PAISAGEM E ANÁLISE AMBIENTAL}

\section{INTRODUÇÃO}

Os espaços livres públicos presentes na paisagem das grandes cidades são caracterizados por trazer inúmeros benefícios que abrangem os âmbitos social, da saúde física e mental, e da qualidade ambiental. Acerca da qualidade ambiental urbana, os espaços livres funcionam como indicadores, devendo ser levado em consideração a quantidade, a qualidade e a distribuição destes espaços na cidade.

De acordo com Lima et al (1994) existe uma enorme confusão na conceituação de termos referentes ao verde urbano. Assim, conceitos como área verde, espaço livre, cobertura vegetal são usados indistintamente como sinônimos e como se desempenhassem a mesma função. (CAVALHEIRO et al, 1999)

Cavalheiro et al (1999) apresentam sugestões acerca destes conceitos, considerando que:

- O espaço livre de construção é o espaço urbano ao ar livre, destinado a usos que tenham relação como caminhadas, descanso, passeios, práticas de esporte e, em geral, a recreação em horas de ócio; os locais de passeio devem ser seguros e estar totalmente separados em relação aos veículos. Os espaços livres podem ser públicos, privados ou potencialmente coletivos, desempenhando funções de estética, de lazer e ecológico-ambiental, entre outras.

\footnotetext{
1 svgeog@yahoo.com.br

${ }^{2}$ Professor orientador
} 
- As áreas verdes constituem-se em tipo especial de espaços livres, onde a vegetação caracteriza-se como o elemento fundamental. Devem satisfazer objetivos ecológicoambiental, estético e de lazer. Pelo menos $70 \%$ da área devem ser ocupados com vegetação e solo permeável.

- A cobertura vegetal é a projeção do verde em cartas planimétricas, podendo ser identificadas por meio de fotos aéreas, sem uso de estereoscopia.

É a partir da Revolução Industrial que se iniciou uma preocupação com a existência de áreas verdes para a população das cidades. Segundo Hennebo (1979 apud LIMA, 1994), na Antiguidade Clássica, talvez o único espaço livre, de uso comum e acessível a todos, tenha sido a Ágora de Atenas que, além de ter sido um local destinado ao culto dos deuses do helenismo, teve também, a função de reunir a população com o objetivo de discutir a política da república.

A questão dos espaços livres tem estreita relação com o tempo livre do indivíduo. No decorrer da história, houve um aumento do tempo livre das pessoas, ou seja, passava-se a ter um tempo disponível para o lazer.

Medeiros (1975) coloca que lazer é o tempo não comprometido, que podemos usar livremente. O lazer engloba uma série de possibilidades como repousar, comer, fazer visitas, ira ao cinema, estádio, ouvir música, assistir televisão, ler jornal, praticar esportes, jardinagem, fotografia, entre outros. Portanto, a recreação é uma maneira de modificar os períodos de folga para não se deixar cair no ócio.

De acordo com Lutzin \& Storey (1973) entende-se por lazer o tempo não obrigatório e recreação a experiência de livre escolha dentro deste tempo não obrigatório que é o lazer.

É de grande relevância, portanto, que os espaços livres públicos ofereçam opções para que as pessoas tenham disponível muitas possibilidades de escolha para sua recreação ao ar livre nos momentos de lazer.

Segundo Nucci (2001) a preocupação por parte dos governantes com o lazer no planejamento urbano sofreu modificações juntamente como a mudanças de ordem econômica e social no decorrer da metade do século XIX e durante o século XX. À medida que aumenta a aglomeração urbana nas cidades, uma especialização das funções que passam a ser cada vez mais tediosas, repetitivas e reivindicações para diminuição da jornada de trabalho, o lazer foi se tornando cada vez mais constante e necessário. 
Ao se estudar a questão da participação popular nas tomadas de decisões acerca do planejamento dos espaços livres nas cidades, parte-se do pressuposto que os cidadãos que vivem em um país cujo sistema de governo é democrático tem liberdade de escolha.

Ao fazer uma correlação entre democracia e planejamento de espaços livres, Gröning (2006) considera que dois pontos parecem ter especial significado. Primeiro, é mais importante conversar com as pessoas, descobrir seus interesses e oferecer assistência para, depois, fazer mais uma outra análise ecológica ou mais um outro estudo de biodiversidade. Segundo, é mais importante aplicar resultados cientificamente provados e criatividade artística do que invocar idéias místicas sobre jardins e paisagens.

As opções de lazer em espaços livres públicos impostos pelo planejamento podem, às vezes, não estar em concordância com as opções desejadas pelas pessoas que residem nas proximidades destes espaços. Outra questão que merece destaque é o fato destes espaços estarem distribuídos de maneira irregular, privilegiando determinadas regiões da cidade.

\section{OBJETIVOS}

O objetivo principal deste trabalho será analisar as opções de usos oferecidos pelos espaços livres públicos (parques, praças e bosques) do município de Curitiba-Pr, tomando por base três situações: as opções de uso oferecidas pelos espaços livres públicos; as considerações acerca do tema feitas por cientistas como arquitetos, psicólogos, sociólogos, engenheiros e geógrafos; e a opinião da população acerca das opções de usos desejadas para estes espaços.

Portanto, este trabalho procurará responder às seguintes questões de estudo:

$1^{\circ}$ ) Quais as opções de lazer em espaços livres públicos oferecidas pelo planejamento público, o que a ciência coloca em relação ao assunto e o que os cidadãos desejam?

$2^{\circ}$ ) Qual seria a configuração da paisagem (mapa) dos espaços livres públicos e suas opções de usos levando-se em consideração o que a ciência considera ideal, o que realmente existe e a opinião da população?

\section{ETAPAS}

Para a realização deste trabalho serão seguidas as seguintes etapas: 
1) Pesquisa bibliográfica sobre dos temas democracia, liberdade, lazer, espaços livres públicos, opções de lazer, planejamento de espaços livres, considerando a evolução histórica;

2) Pesquisa específica dos espaços livres públicos em relação a: quantidade e a distribuição; as opções de usos oferecidas; os problemas do planejamento urbano em relação aos espaços livres públicos, considerando o fato de que certos usos previstos não funcionam; os índices de espaços livres considerados como "ideais" na literatura;

3) Pesquisa para elaboração de questionário;

4) Consulta à população sobre opções de lazer: questionários aplicados aos freqüentadores dos parques e praças, às associações de moradores dos bairros e às escolas.

5) Apresentação de uma cartografia de opções e versão final da tese.

Palavras-chave: espaços livres, opções de lazer, Curitiba.

\section{BIBLIOGRAFIA}

CAVALHEIRO, F.; NUCCI, J. C.; GUZZO, P.; ROCHA, Y. T. Proposição de terminologia para o verde urbano. Boletim Informativo da SBAU (Sociedade Brasileira de Arborização Urbana), ano VII, n.3 - Jul/ago/set de 1999, Rio de Janeiro, p.7.

GRÖNING, G. Aspectos da cultura do jardim e do desenvolvimento dos espaços livres na Alemanha. Revista RA'E GA. Curitiba: Editora UFPR. n. 11, p. 143-170, 2006.

LIMA, A. M. L. P.; CAVALHEIRO, F.; NUCCI, J. C.; SOUZA, M. A de L. B.; FIALHO, N de O.; DEL PICCHIA, P.C.D. Problemas de utilização na conceituação de termos como espaços livres, áreas verdes e correlatos. II Congresso Brasileiro de Arborização Urbana. São Luís, de 18 a 24 de setembro de 1994, p.539-549.

LUTZIN, S. G. \& STOREY, E. H. Managing municipal leisure services. The municipal Management Series, Washington, DC, International City Management Association, 1973, 282p.

MEDEIROS, E. B. O lazer no planejamento urbano. FGV-RJ, 1975, 253p.

NUCCI, J. C. Qualidade ambiental e adensamento urbano. São Paulo: Humanitas/Fapesp, 2001, 236 p. 